\title{
Cluster Essay How to kiss a leper
}

\author{
Julie Orlemanski \\ Department of English, Boston College, Boston, MA.
}

\begin{abstract}
Episodes of kissing lepers appear in medieval holy lives from Sulpicius Severus's late-fourth-century vita of Martin of Tours to the early-fifteenth-century spiritual autobiography of Margery Kempe. How exactly did the leprous kiss function within medieval society? The following essay explores that question by way of a 'historical phenomenology,' or investigation into what kind of experience kissing a leper was imagined to be in the Middle Ages. Building from the observation that the affective shock of the kiss gave it its medieval value, the essay argues that the gesture was understood to disrupt quotidian practices of recognition, defamiliarizing the faceto-face encounter and opening new perceptual and intersubjective possibilities. However, medieval narrative representations are generally one-sided, focusing almost exclusively on the experience of the able-bodied. While the leprous kiss pushed experiential and social limits, these ran up against the asymmetry of the kiss's imagining, the solipsism of its intimacy.
\end{abstract}

postmedieval: a journal of medieval cultural studies (2012) 3, 142-157. doi:10.1057/pmed.2012.11

He's a leper licker. Shrike says he wants to lick lepers. Barkeep, a leper for the gent.

Nathanael West, Miss Lonelyhearts

In 2003 Robert McRuer and Abby Wilkerson chose to entitle their co-edited special issue of GLQ, which addressed the meeting of queer theory and disability studies, Desiring Disability. Their title is a phrase signifying in at least two directions at once, toward the longing for intimate contact with disabled 
persons and toward the wish to be disabled oneself. Both senses disturb common-sense assumptions about what is attractive. One medieval gesture, a social form that I call here the 'leprous kiss,' plays upon both these aspects of desiring disability - the wanting to be with and the wanting to be disabled. In the high and late Middle Ages, Christians acted on the belief that intimate care for the physically infirm and empathic identification with their state were acts of religious devotion and opportunities for spiritual transformation. Within such a field of social value, the kissing of lepers stood out as a particularly charged possibility. Reflecting on this gesture in the context of present-day disability studies demands that we shift the focus of most medieval representations of the leprous kiss, to encompass the 'enunciated subject position' of the leper him- or herself, in addition to that of the pious Christian (Snyder and Mitchell, 2006, 176). Yet a further meaning of 'desiring disability' asserts itself - not the double desire for disability, but the desires expressed and experienced by individuals occupying the position of 'extraordinary embodiment' (to invoke the elegantly flexible phrase of Rosemarie Garland Thomson, 1997).

Episodes of kissing lepers appear in holy lives from Sulpicius Severus's latefourth-century vita of Martin of Tours to Raymond of Capua's Legenda of Catherine of Siena, completed in 1395. The most influential of such narrations occur in the various lives of Francis of Assisi. The narrative and affective paradigms crystallized in the Franciscan kiss continued to inform devotional discourse and practice through the remainder of the Middle Ages, shaping the content of sermon exempla, patterns of charitable giving, and the lives and lifewritings of such pious figures as Angela of Foligno (d. 1309). The kiss's ongoing imaginative force, for instance, is evident in the spiritual autobiography of Margery Kempe, chronicling the English laywoman's eventful life in the early fifteenth century. Margery represents her wish to 'kissyn the lazerys [lepers] whan sche sey hem er met wyth hem in the stretys' as impinging on her with such urgency that it caused her 'gret mornyng and sorwyng.' Eventually receiving the permission of her confessor, she 'went to a place wher seke women dwellyd whech wer ryth ful of the sekenes, and fel down on hir kneys beforn hem, preyng hem that sche myth kyssyn her mowth for the lofe of Jhesu' (Kempe, 2004, 326-327). What kind of intimacy, what kind of recognition, does this impassioned demand imply? In interpreting the plea for a kiss on the mouth, how do we readers understand the crackling circuits of desire, meaning, identification and power that run between Margery, the 'seke women,' 'Jhesu' and ourselves? What can the kiss tell us about medieval practices of 'desiring disability'?

In the following pages, I describe the particular experiential form of this physical encounter, the phenomenology scripted in representations of the leprous kiss. I suggest that the gesture was understood to disrupt quotidian practices of recognition, defamiliarizing the face-to-face encounter and inciting new perceptual and intersubjective possibilities. However, medieval representations of the kiss are generally one-sided, focusing almost exclusively 
1 Baswell (2003); Metzler (2006); Wheatley (2010); Pearman (2010); Singer (2010); Eyler (2010); Metzler (2011). on the experience of the devout and able-bodied osculans. These stories' broader implication, that the leprous subject co-creates new models of intersubjective relation, disappears with the subject's narrative instrumentalization, his or her discharge of an epiphanic 'function' in the story, and subsequent vanishing. While the leprous kiss posed new experiential and intersubjective possibilities in the Middle Ages, these ran up against the asymmetry of its imagining, the solipsism of its intimacy.

Before pursuing these arguments, I offer a quick note about the historical project of 'medieval disability studies' and leprosy's perhaps unique place within that project. The equation of medieval leprosy with disability is, in a basic sense, anachronistic, given that no social category in the Middle Ages signified quite what 'disability' does today (Metzler, 2006, 4-6). The viability of 'medieval disability studies' depends upon the license, and the critical and constructive desire, to overlay identities as historically discrete as leprosus and 'disabled,' to unfold their genealogical relationship and reveal, through mutual illumination, potentialities in each. A small but growing collection of books and articles attests to the liveliness of the challenge. ${ }^{1}$ Regarding leprosy in particular, some might protest that it is a sickness rather than a disability, and indeed the distinction between impairment and chronic disease has been a vexed one within disability studies. To my mind, the exemplary status of leprosy in representing physical infirmity and institutionalizing practices of care in the Middle Ages demands the pathology's inclusion within 'medieval disability.' Unsettling accepted categories, after all, is one of the results we might expect from the historical dimension of disability studies.

Among physical impairments leprosy arguably represents a kind of limit-case to the establishment of cross-temporal continuities and identities - because what the disease often signifies in today's symbolic economy is, precisely, epochal difference. The leper has come to be the grotesque embodiment of historical alterity itself. The pathology caused by Mycobacterium leprae is generally referred to today as 'Hansen's disease' to dissociate the medical condition from the stigma carried by 'leprosy.' Although worldwide two to three million people are estimated to be permanently disabled by the effects of Hansen's disease, for better or worse Western culture tends to quarantine 'leprosy' in biblical and medieval temporalities. Consequently, leprosy's current rhetorical force lies in establishing systems of bodily difference across historical periods, for instance, in designating HIV/AIDS the 'leprosy of our time' (among many, Saaymen and Kriel, 1992). Leprosy, then, might be taken to be illness and disability in 'temporal drag' - to borrow a phrase from the work of queer studies scholar Elizabeth Freeman. For Freeman, 'temporal drag' encompasses both the queer performative potential of the drag queen and 'all of the associations that the word "drag" has with retrogression, delay and the pull of the past on the present.' To think about lepers in the context of disability studies is to think about the 'temporal incongruity' of bodies, modes 'of stubborn identification with a set of 
social coordinates' that have exceeded their own historical moment, and this " "drag” as a productive obstacle to progress, a usefully distorting pull backwards, and a necessary pressure upon the present tense' (Freeman, 2000, 728).

While use of the term 'leper' is controversial in contemporary scholarship, I follow historian Carole Rawcliffe in employing it to reflect the vocabulary of medieval sources (Rawcliffe, 2006, 11-12). Moreover, the critical reclamation of other stigmatizing labels, like 'queer' and 'crip,' suggests the potential generativity of the term (Butler, 1993; McRuer, 2006). Although beyond the scope of the present essay, analysis of the modern circulation of 'leper' may help us to analyze the relationships among embodiment, pathology and perceived historical difference - for instance, how outbreaks of leprosy in colonial populations in the nineteenth and twentieth centuries were understood through medievalizing paradigms, or why Michel Foucault might have opened Folie et déraison with a striking gesture of periodization that contradicts known historical fact: 'At the end of the Middle Ages, leprosy disappeared from the Western world' (Foucault, [1972] 2006, 1).

I chose the epigraph of this essay from Nathanael West's 1933 novel Miss Lonelyhearts - from which Erving Goffman also drew the epigraph of his seminal study, Stigma: Notes on the Management of Spoiled Identity, now considered part of the foundation of disability studies (Davis, 1997, 4, 203-215; Thomson, 1997, 30-32). In some ways Miss Lonelybearts is a difficult read, a cocktail of ugly feelings, dark comedy, abjection and 'temporal drag.' Just a few sentences after one of Miss Lonelyhearts's drinking partners calls the otherwise unnamed male advice-columnist a 'leper-licker,' another companion marks him out explicitly as a quasi-medieval anomaly: 'Well, that's the trouble with his approach to God. It's too damn literary - plain song, Latin poetry, medieval painting, Huysmans, stained-glass windows and crap like that' (West, 1933, 14). The drunken men's jokes at the expense of the queer figure of Miss Lonelyhearts suggest the ambivalence of 'desiring disability' and the potential convergence of corporeal, sexual and temporal difference that the 'leper' marks. This essay's title, 'How to Kiss a Leper,' mimes the uneasy advice-column rhetoric of Miss Lonelyhearts, a rhetoric that opens onto contact and intimacy even as it performs its own distance from those it would reach.

$* * *$

What, then, did the leprous kiss mean and enact within medieval society? Because the affective, experiential punch packed by the kiss was a significant component of its value, one approach to answering such a question is by way of a kind of 'historical phenomenology,' or an investigation into what kind of experience kissing a leper was imagined and represented to be in the Middle Ages. Leprosy and the kiss, I suggest, were understood to share a certain tendency to make strange the human face, the aspectus or species - those Latin words for 'face' that also denote appearance as such. In different ways, both 
gesture and disease interfere with and transform the everyday phenomenality of other people. In combining the already complex experiential and ethical dimensions of leprosy and of the kiss, the leprous kiss strained the appeal of the human form and reimagined its power.

A kiss is - to be literal - an interface: it is paradigmatically what is between faces, an event, an experience, an exchange of touch, the shared and mutually constituted pressure between two surfaces. In the act of kissing, the space of recognition, the zone between bodies that we look across and speak across in meeting one another, is drawn down toward zero. Isidore of Seville, in a passage much cited in the Middle Ages, etymologizes, 'The face [facies] is named from "likeness" [effigie], since it reflects the entire form of a man [tota figura hominis] and the mind [cognitio] of each person' (Isidore of Seville, 1996-2011, 82: 401b; translation mine). In bringing our faces closer and closer together to kiss, however, Isidore's visible 'likeness' of the whole personality is overwhelmed. The face's scale changes, and with it, the experience and meaning of the face change, too. Physiognomic observation and conversational exchange dwindle and fold into the tactile; they intensify into the tactile.

It is this qualitative transformation of recognitive modes that renders Judas's kiss such a powerful theme of medieval iconography: the interface of divine face and betrayer's marks radical division as well as contact. Ambrose of Milan (d. 397) went so far as to deny that this infamous kiss was a kiss at all: 'So the Pharisee had no kiss, except perhaps for the kiss of the traitor Judas. But Judas had no kiss either .... It is not the kiss of the lips which is required, but the kiss of the heart and mind' (cited from Perella, 1969, 28). The power of the kiss to constitute relationality took on new prominence in the twelfth century, when commentaries on the Song of Songs by Bernard of Clairvaux and William of Saint-Thierry systematically elaborated the kiss's metaphorical significance. When Bernard begins his series of sermons by demanding, 'Tell us, I beg you, by whom, about whom, and to whom it is said: "Let him kiss me with the kiss of his mouth"?' he places questions of relationality at the heart of his network of metaphors (Bernard of Clairvaux, 1971, 3). Though distinguishing osculans from osculatum, Bernard made the kiss the condition of mutuality between the two, proceeding as much from one as from the other, "common both to him who kisses and to him who is kissed' [osculanti osculatoque commune est] (Bernard of Clairvaux, 1971, 46). The kiss, then, is imagined as the enjoyment of those conditions of reciprocity that it itself generates.

Kissing of course was not only written about but also practiced, serving as a key element in the idiom of ritual gestures in medieval Europe. Among the different contexts for socially binding kisses were the giving of gifts, renouncing of disputed claims, the oath of feudal homage and the ceremony of marriage. The most common and widely experienced of ritual kisses was the liturgical kiss of peace, the so-called pax, which was exchanged among members of the congregation in the course of the mass (Koslofsky, 2005, 20). The work of the 
pax was precisely to express, and to produce, the real unity of the Christian community. Augustine remarks on the emotional watchfulness incumbent upon each Christian in performing the pax:

After [the Lord's Prayer], the 'Peace be with you' is said, and the Christians embrace one another with the holy kiss. This is a sign of the peace; as the lips indicate, let peace be made in your conscience, that is, when your lips draw near to those of your brother, do not let your heart withdraw from his. (Augustine, 1959, 197-198)

To effect this coincidence of lips and of hearts, the medieval subject could rely on the power of gestures to shape feeling, described by Thomas Aquinas when he writes that 'Man performs certain sensible actions, not to arouse God, but to arouse himself to things divine .... For experience shows that by acts of the body the soul is aroused to a certain knowledge or affection' (Thomas Aquinas, 1928, 102). According to the understandings of Augustine and Aquinas, the kiss is transformative both because as members of an expressive community we have an obligation to feel in conformity with the kiss's social meaning and because the act of kissing inevitably redounds upon our affections and knowledge.

Alongside the kiss's normative function of community-building, its ineradicable eroticism influenced its liturgical fate. John Bossy notes that 'ecclesiastical nervousness had substituted for Augustine's kiss on the lips a kiss on the cheek, and women were supposed to be divided from men in the congregation so that each would only kiss among themselves' (Bossy, 1983, 55). Despite such measures, in the later Middle Ages the kiss shared between communicants came to be replaced by the use of an osculatorium, or pax-board, an ornamented plaque passed around the congregation for each to kiss in turn. The custom is first recorded at York in 1250 and spread to France in the early fourteenth century. By 1500 it had replaced completely the exchange of kisses throughout the Western Church. In his study of the same period, J. Russell Major connects the disappearance of the ceremony of homage, which involved a kiss on the mouth, to the tightening of social mores concerning same-sex kissing. In the fragmentary, shadowy history of the kiss, the end of the Middle Ages seems to be a period of curtailing its ritual efficacy, even as the leprous kiss maintained, if not increased, its imaginative power (Major, 1987).

Leprosy, like the kiss, was understood to defamiliarize the phenomenality, the appearing and appearance, of other people. Medical writers frequently defined leprosy in terms of its destruction of bodily form. It is a disease 'corrupting the figure and the form and the composition of the body's parts and finally dissolving [the body's] wholeness '[Lepra est morbus consimilis corrumpens figuram et formam et compositionem membrorum et finaliter solvens continuitatem]', writes Bernard of Gordon in his 1305 Lilium Medicinae (Demaitre, 2007, 112-113; translation mine). Guy de Chauliauc, in 1363, 
2 Orthography modernized, here and following. describes leprosy as a disease 'qua forma corrumpitur in toto,' or, in the words of one of his Middle English translators, 'by the whiche the fourme (i. schappe) is corupte in alle the body.' Guy's text also gives a particularly vivid image of the disease's ravaging of bodily form in its etymology of lepra, which 'is saide of the worde lupus, a wolfe, for it devoureth alle the membres as a wolf doth. It roteth forsothe all the membres as a cancrouse wolf' (Ogden, 1971, 378). ${ }^{2}$ Forma, figura, compositio and bodily continuitas are all vulnerable to leprosy's 'devouring.'

Moreover, the disease had a special reputation for disfiguring the face. Diagnostic attention focused almost obsessively on facial features. The Middle English translation of Guy de Chauliac, for instance, urges its reader to consider the patient's visage meticulously, 'for the tokenes of the face ben moste certeyne,' and after the entire diagnostic exam has been completed, 'he schal go agayne to the consideracioun of the face and of the loke' (Ogden, 1971, 382). Medical categorizations of leprosy describe the metamorphosis of the sufferer's physiognomy according to strange resemblances, to a lion, an elephant, and a satyr. In the romance descriptions of lepers, in shrine records of miraculous cures, and in hagiographical narratives, severe facial disfigurement is ubiquitous. An exemplum from Caesarius of Heisterbach's early thirteenthcentury Dialogus Miraculorum describes a leper with a 'face [aspectus] so horrible and, as it were, gnawed away by leprosy, that the human eye could not observe him without being tortured [cruciatu]' (Caesarius of Heisterbach, 1851, 106; translation mine). Gerald of Wales seems almost to relish the deformities of the lepers whom Hugh of Lincoln visits:

No deformity of leprosy, even where there was no shape of mouth or lips, but only the teeth projecting outward, could frighten him away from them. Through the great humility of his devotion and the warmth of his charity, he had no horror of imprinting a kiss on a form more monstrous than human [monstruose magis quam forme humane osculum inprimere]. (Gerald of Wales, 1985, 30-31)

The cumulative effect of such descriptions is to make the leper a figure for disfiguration itself. It is then in the rigorous aesthetic sense that the leper's face may be called sublime: it verges on the limits of perception and of representation and makes those limits themselves sensible.

The link between leprosy and an embodied sublime is put forward most influentially in the comparison of the Man of Sorrows to a leper in Isaiah, the best known and most concentrated passage of prophetic imagery of the suffering Christ:

Non est species ei, neque decor, et vidimus eum, et non erat aspectus, et desideravimus eum: despectum, et novissimum virorum, virum dolorum, et scientem infirmitatem, et quasi absconditus vultus ejus et despectus, unde nec reputavimus eum. Vere languores nostros ipse tulit, et dolores 
nostros ipse portavit; et nos putavimus eum quasi leprosum, et percussum a Deo, et humiliatum. (Isaiah 53: 1-4)

Ther is not shap to hym ${ }^{3}$ ne fairnesse and wee seeyen hym and he was not of sihte and we desireden hym dispisid: and the laste of men man of sorewis and witinge infirmyte/and as hid his cheere and dispisid: wherfore ne wee setteden bi hym/verreli our sikeness he bar and oure sorewis he bar/and wee heelden hym as leprous: and smyten of god and mekid. (Lindberg, 1959, 154)

The Middle English of the Wycliffite Bible does not shy away from the lines' paradoxical character when it translates, 'wee seeyen hym and he was not of sihte,' or, in the later version, 'we sien hym, and no biholdyng was.' These verses grapple with the description of the radical formlessness layed out in the first clause, 'Non est species ei [ther is not shap to hym].' This formlessness is finally figured through leprosy - 'quasi leprosum' - a stable signifier for the loss of human shape. As one Middle Netherlandish devotional tract reads, 'But $\mathrm{He}$ [Christ] had not the form of a man, because one reads that our beloved Lord's holy face was so miserably transformed and disfigured as if he had been a leprous man' (cited from Marrow, 1979, 53).

In medieval writings generally, the human face is valued as being superior to, if not almost ontologically distinct from, the rest of the body. It is 'la plus digne partie et la plus eslevee et plus digne de tout le corps humaine' '[the worthiest and loftiest part, the worthiest of the entire human body], exalts Le Livre des Eschez Amoureux Moralisés (Evrart de Conty, 1993, 30; translation mine). The leprous kiss - in drawing together two faces (one of which is spectacularly altered by disease), in bringing them together to the point of touching - makes tangible the fact that the face does not transcend the body, despite being 'la plus digne partie.' A person does not transcend his or her persona, or the physical medium that is 'sounded through,' like a theatrical mask. In this way, leprosy's pathological potential to assert the 'body in the face' also discomfits the relatively unmarked embodiment of the pious osculans. This is perhaps the kiss's most powerful function: to render palpable the shared dimension of material vulnerability. Such mutuality stands in contrast to the affect of disgust and the radical bodily difference to which disgust seems to refer.

The disruptive, transformative and utopian possibilities immanent to the leprous kiss frequently depend upon the amplification of physical difference as well as contact across this difference. Beginning in the twelfth century, the Church was placing new emphasis on the seven corporal works of mercy. The ascendance of the mendicant orders, the beguine movement in the Low Countries, and the founding of new hospitals and hospital orders gave institutional shape to charity's new imperative to intimacy. In a sermon intended for hospital workers, for instance, Jacques de Vitry reminds his listeners that they should themselves provide physical care for the afflicted, 
4 Non solum enim per ministros sed per vos ipsos debetis visitare infirmos et eis ministrare manibus propriis levando portando et ad lectos reportando. $\mathrm{Hec}$ enim valde placent Deo.... Hec enim, humilitatis officia multum provocant ad compassionem et ad infirmitatis vestre cognitionem [Indeed, not only in the person of caregivers but you yourselves must visit the sick and attend to them, lifting and carrying and returning them to their beds with your own hands. For these things please God very much. .... Indeed, these services of humility greatly provoke compassion and the recognition of your own weakness] (cited from Farmer, 2005, 94 n55; translation mine) rather than delegating the task, because it is one's own interpersonal contact with the sick that provokes a sense of compassion. ${ }^{4}$ Leprosy, which served as a symbol of bodily sickness in general, took on increasing importance as a catalyst for devotional expression (Bériou, 1991, 41; Demaitre, 2007, 82). In this context two common patterns found in narrative representations of the leprous kiss suggest the systematic limitations to such charitable modes of 'desiring disability'. The first is the exaggeration and naturalization of the affect of disgust; and, second, the ultimate disappearance of the leprous subject.

All of the major accounts of Francis of Assisi's life take pains to stress the saint's original disgust for lepers. Thomas of Celano describes Francis as 'abhorring [them] naturally [naturaliter abhorrens],' and in fact, 'So greatly loathsome was the sight of lepers to him at one time, he used to say, that, in the days of his vanity, he would look at their houses only from a distance of two miles and he would hold his nostrils with his hands' (Habig, 1983, 369, 242-243). The 'Legend of the Three Companions' recounts:

He had always felt an overpowering horror of these sufferers .... Formerly he could neither touch or even look at lepers .... Indeed his previous aversion to lepers had been so strong, that, besides being incapable of looking at them, he would not even approach the places where they lived. And if by chance he happened to pass anywhere near their dwellings or to see one of the lepers, even though he was moved to give them alms by some intermediate person, he would nevertheless turn his face away and hold his nose. (Habig, 1983, 900-901)

Given the exaggerated rigors of disgust, the slightest proximity to lepers becomes its own kind of suffering, a suffering that awaits transformation in the alchemy of penance and imitatio Christi. Jacques de Vitry even describes hospital workers in the terms of martyrs:

They have endured so great and so many impurities of the sick, and such intolerable stench, bringing violence upon themselves, that I judge that no other form of penance is able to be compared to this martyrdom. (Farmer, $2005,83)$

Infirmorum immundiatis et fetorum molestias pene intolerabiles, sibimet violentiam inferentes, quod nullum aliud penitentie genus huic sancto et pretioso in conspectu dei martyrio posse arbitrer comparari. (Jacques de Vitry, 1972, 148)

The visceral nature of the affective labor necessary to reverse disgust into love is memorably articulated in Raymond of Capua's 1395 Legenda of 
Catherine of Siena. When Catherine uncovers the stinking ulcer of a patient, she is seized with repulsion: 'Her stomach was upset by the intolerable odor, and she was on the point of vomiting.' In response she rebukes herself, asking, 'Are you disgusted..., you who may well end up yourself by falling into the same malady, or a worse one?' Catherine's squeamish quavering provides the occasion for her self-transformation, as she extends the regime of Christian symbolic transvaluation over her roiling stomach: 'Immediately she bent over the sick woman and pressed her mouth and nose to the festering sore, and in that posture she remained a long time, until she felt that the power of the spirit had subdued the nausea of the flesh' (Raymond of Capua, 1980, 149). Moroever, when Catherine's mother exclaims, 'Daughter, ... you will surely catch the leprosy yourself,' and Catherine's hands show signs of the disease, it is clear that by the late Middle Ages, contact with lepers was understood to carry the risk of contagion (Raymond of Capua, 1980, 140). ${ }^{5}$

In Francis's and others' accounts of the leprous kiss, disgust and its concomitants provide a kind of affective heat fueling the spiritual transformations produced out of the kiss. Accounts of caring for the sick often present two disfigured, unruly, extraordinary bodies - one racked by the effects of disease, and one by subjective reactions to it. Face to face, infected and affected mirror one another in a moment of near-uncontrollable physicality, which piety takes as its opportunity for spiritual metamorphosis. Producing a certain frisson of disgust in the reader is also part of the rhetorical labor of such accounts. The reader's repugnance manifests the difference between his or her own reactions and the holy person's heroic feats of love. Alongside Sarah McNamer's recent work on medieval compassion within the 'history of emotions,' it would be of interest to track the vicissitudes of disgust. Does repulsion act as a kind of handmaiden affect, necessary for the generation of certain intensities of sympathy and certain types of desire?

In Bonaventure's Vita Maiora, the authorized and most widely influential of the Franciscan lives, the saint's transformative kiss takes place when Francis is a young man, riding on horseback on the plain below Assisi. He unexpectedly comes upon a leprous man and, given his marked aversion to lepers, 'felt sick at the sight of him.' Remembering his need to 'overcome himself' in order to be a knight of Christ, Francis dismounts to kiss the man and give him alms. When he mounts his horse again, he 'looked this way and that about the plain with a clear view in all directions, but there was no sign of the leper. He was thunderstruck but his heart was filled with joy' (Habig, 1983, 638). This narrative pattern, of a kiss followed by the leper's vanishing, was to be repeated in many subsequent medieval accounts: the leper is both embraced and spirited away by the devout person's gesture, somehow sublated by the action of the kiss. Another typical example tells the story of the devout nobleman Theobald, who one day washes a leper's feet only to discover later that the leprous man had actually died some time before. ${ }^{6}$ The body that Theobald has handled and touched and cared for in 
6 For a Middle English version, see Brandeis, 1900, 247. fact is Christ's - or as the rubric of the exemplum reads, he 'washed the feet of Christ, in the figure of a leper [in figure leprosi, Christi pedes lavit]' (Caesarius, 1851, 105; translation mine). It is a matter of emphasis and interpretation whether such stories at heart explore the contact shared between passible bodies or rather fantasize the elimination of bodily corruption and vulnerability.

The narrative disappearance of leprosy's corporeal difference is also accomplished through miracles of healing. The kiss frequently 'solves the problem' of the leprous body as it were, overcoming the notorious incurability of the disease. This is the achievement of the earliest recorded version of the leprous kiss, a passing incident in Sulpicius Severus's catalog of the miracles of Martin of Tours, which stood out for special notice in the medieval reception of the life (Peyroux, 2000, 182). 'To the horror of all,' the brief account narrates, Martin 'kissed the piteous face of a leper and blessed him; the man was cured instantly and appeared, his skin glowing, at church the next day' (cited from Peyroux, 2000, 180). The thaumaturgical records of various saints' shrines indicate that the healing of leprosy was among the most noteworthy proofs of a relic's power. Even when there is no miraculous cure or heavenly ascension, the leper usually exits the story after the kiss, occluded by a narrative progress that treats the embrace as a passing episode in someone else's tale.

The leper might also be symbolically effaced. Just prior to Margery Kempe's excursus on her desire to kiss lepers, she recounts that:

sche myth not duryn [dare] to beheldyn a lazer [leper] er another seke man, specialy yyf he had any wowndys [wounds] aperyng on hym. So sche cryid and so sche wept as yyf sche had sen owr Lord Jhesu Crist wyth hys wowndys bledyng. And so sche dede [did] in the syght of hir sowle, for thorw [through] the beheldyng of the seke man hir mende was al takyn into owr Lord Jhesu Crist. (Kempe, 2004, 325-326)

Margery weeps 'as if' she had seen 'our Lord Jesus Christ with his wounds bleeding' - 'And so she did.' The allegorical immediacy of her perceptions renders the leper and other sick or wounded persons so many dissolving signifiers, fading at once to reveal the body of Christ. In the Gospel of Matthew, when Jesus enumerates what were to become the corporal works of mercy (Matt, 25:35-40), he concludes, 'Amen I say to you, as long as you did it to one of these my least brethren, you did it to me.' As the corporal works became more important in religious practice, Christ's words came to guarantee the divine significance of charitable care. The story of Theobald, cited above, concludes by quoting exactly this biblical principle: 'Quicquid uni ex minimis meis fecistis, mihi fecistis.'

The final instance of a leprous kiss I discuss here is from a mid-fifteenth-century Middle English sermon on humility, a translated version of an exemplum found in Caesarius of Heisterbach's Dialogus Miraculorum. The narrative relies on the conventions of both disgust and disappearance, but I close with it because it 
nonetheless dramatizes the ongoing potential of the leprous kiss to quicken new modes of 'desiring disability.' The story begins, 'A bysshop in fraunce wesschyd leprys feet. The bysschop mette be the weye a lepre. The bysschop kyssed him' (Brandeis, 1900, 247). Notable for its staccato parataxis, the opening sets out the story's players in bare and conventional terms. It also establishes a confrontation between iterative practice and singular event, general and particular: the bishop washes many lepers' feet, but one day meets a certain leper.... Sticking close to the model of St. Francis, the bishop promptly kisses the sick man.

It is then that the exemplum turns:

The lepre seyde: 'Bysschop, for thi lownes [humility], wype wyth thi tunge oute of my nase the snevyl that hangyth ther-inne, for I may noht suffere no lynen cloth towche it, for it is so sore.' The bysschop wyth his tunge lykkyd it out lowly [humbly]. And in his lykkyng, sodeynly out of the leprys nose fel a precyous ston in-to the byschopys mowth, schynyng bryht \& swete smellynge. \& forth-wyth, in the syht of the bysschop, the lepre stye up [ascended] to heven. (Brandeis, 1900, 247)

The leper speaks, and one is struck by the sudden thickening and enriching of the story's language. Narrative motion slows, and the nuances of embodiment - the bishop's, the leper's and the reader's own - become palpable. This language revivifies (in part through disgust) the force of intimacy. It opens up the question of what a kiss is: not only an erotic or devotional token, but the contact between the moist surfaces of two bodies, perhaps cringing with pain, with nausea, with shame, but also vibrating with some species of desire. The point of view of the narrative shifts, from a spectator-like perspective on the tableau to the recognitive interval between one visage and another, and finally to the tactile interface between faces, the kiss.

What stands out most in the story, what is exceptional, is the leper's own demand and desire. The leper is first kissed one dutiful kiss as an exercise of piety. He then asks for a revision of that kiss, a re-envisioning of kissing. He demands an act of intimacy and care that is responsive to the conditions of his extraordinary embodiment. Striking for its ethical imagination, the exemplum encompasses both the bishop's charitable pleasure in the leper and the specific sensations and desires originating within the leprous subject. If still reliant on disgust and on the disappearance of the disruptive body, the story also brims with affective and ethical power.

$$
* * *
$$

Some of the most salient critiques offered by disability studies scholars over the past 30 years have concerned the blinkered perspectives shaping practices of 'care.' Among other insights, these critiques have produced new understandings of the ethics and politics of touch, of the haptic encounters between disabled 
7 Dinshaw is far from unaware of such encompassing circumstances. See Dinshaw (1995) for a succinct exposition of method. persons and medical practitioners, family members, lovers and strangers (for instance, Price and Shildrick, 2002). Such scholarship's timeliness has been demonstrated in the reform of existing institutions and in the cultivation of new vocabularies for the demands and experiences of disabled persons.

A number of complications arise in trying to relate such an activist scholarship, focused on the present, to medieval sources. How are the gestures and caresses of the past, and of the cultural imaginary, to be linked to the contact taking shape between persons now, and to the intimacy between present and past, and the interface of embodied experience and representation? In this essay I have hesitated to move too quickly to condemn the leprous kiss in the Middle Ages, despite the fact that when considered from the leper's 'enunciated subject position,' it often appears more imposition than communion. How does one square a person's claim to determine his or her own intimacies with the creation of new forms for desire? Attempting to focus my perspective on the medieval leper returns me to the postures of Francis of Assisi and Catherine of Siena and Margery Kempe: seeking corporeal and moral solidarity, which in practice always remains incomplete but does produce a certain kind of contact. I am thrown back on the ironic task set out in this essay's title, to tell my reader 'how to kiss a leper' - as if I might ever have been able to say how to desire disability properly, rather than standing within the circuits of desire I observe.

If Margery Kempe's instantaneous hermeneutics of seeing 'owr Lord Jhesu Crist' in every 'lazer' or 'seke man' seems to pass without friction through the infirm body to Christ, the very gesture of the kiss stops her, and stops us, on the surface of the signifier. This is one effect of kissing, of the tactilely mobile pressure between contiguous bodies. In combining the aleatory palpations of touch with the disjunctive corporeality of leper, the leprous kiss would seem to participate in Carolyn Dinshaw's idea of 'the touch of the queer,' about which she writes, 'I speak of the tactile, "touch," because I feel queerness work by contiguity and displacement; like metonymy as distinct from metaphor, queerness knocks signifiers loose, ungrounding bodies, making them strange, working in this way to provoke perceptual shifts and subsequent corporeal response in those touched' (Dinshaw, 1999, 151).

Nonetheless, it seems to me that the project of a critical disability studies entails examination of the social and representational circumstances within which such touching takes place. It should inquire into how the emancipatory potential of touch is bound up, in this case, with the naturalization of disgust and with the imperative of the leper's disappearance. ${ }^{7}$ Perhaps the special value of disability studies for the rather venerable medievalist topic of the 'history of the body' is to insist upon the claims that disabled persons in the past, and those in the present, exert on our scholarship. As we explore the nature and significance of those claims, we can hope to develop methods of inquiry responsive both to the potential for 'ungrounding bodies' and to the grounds of such ungrounding. 
Noli me tangere, Christ's words to Mary Magdalene when they meet outside his empty tomb, might be thought of as the lost or repressed possibility of the leper's speech-act within depictions of the leprous kiss. Christ's words hold his extraordinary body apart, establishing the speaking self's jurisdiction over the resource of affect, sensuous experience, and knowledge that his body has become for others. Does Noli me tangere form the necessary flipside of the leprous man's request, in the Middle English exemplum, that the bishop revise his kiss in light of the particularity of embodiment and desire? Does the sovereign refusal of touch make up the inner lining of any authentic exchange of desires? The rights and claims of individual identity within imaginative social forms remain one of the undecided issues within the historical and literary dimensions of disability studies. The point of contact between voice and body, jurisdiction and touch, Noli me tangere and the kiss - rather than the decision between them - is the interface at which for now I close.

\section{About the Author}

Julie Orlemanski is Assistant Professor of English at Boston College. She received her PhD in 2010 from Harvard University. Her writings appear (or are forthcoming) in Exemplaria, Journal of Medieval and Early Modern Studies, and A Handbook of Middle English Studies (Wiley-Blackwell). She is currently at work on a study of representations of disease entitled 'Symptomatic Subjects: Bodies, Signs, and Narratives in Late Medieval England.' Her research interests include the history of science and medicine, embodiment, exemplarity, and genre (E-mail: julie.orlemanski@bc.edu).

\section{References}

Augustine. 1959. Sermons on the Liturgical Seasons, trans. M.S. Muldowney. New York: Fathers of the Church.

Baswell, C. 2003. King Edward and the Cripple. In Chaucer and the Challenges of Medievalism: Studies in Honor of Henry Ansgar Kelly, eds. D. Minkova and T. Tinkle, 15-28. Frankfurt, Germany: Peter Lang.

Bériou, N. 1991. Les lépreux sous le regard des prédicateurs d'après les collections de sermons ad status du XIIIème siècle. In Voluntate dei Leprosus: Les lépreux entre conversion et exclusion aux XIIème et XIIIème siècles, eds. N. Bériou and F. Touati, 33-80. Spoleto, Italy: Centro Italiano di Studi Sull'alto Medioevo.

Bernard of Clairvaux. 1971. On the Song of Songs I, trans. K. Walsh. Spencer, MA: Cistercian Publications.

Bossy, J. 1983. The Mass as a Social Institution 1200-1700. Past and Present 100(1): 29-61.

Brandeis, A., ed. 1900. Jacob's Well: An English Treatise on the Cleansing of Man's Conscience, EETS o.s. 115. London: Trübner. 
Butler, J. 1993. Critically Queer. GLQ: A Journal of Lesbian and Gay Studies 1(1): 17-32.

Caesarius of Heisterbach. 1851. Capitulum XXXI, De Theobaldo Comite qui in figura leprosi, Christi pedes lavit (Capitulum XXXII, De Episcipo qui leprosi nares lingens, gemmam decidentem suscepit). In Dialogus Miraculorum, ed. J. Strange. Cologne, Germany: J. M. Heberle.

Davis, L.J. 1997. The Disability Studies Reader. New York: Routledge.

Demaitre, L. 2007. Leprosy in Premodern Medicine: A Malady of the Whole Body. Baltimore, MD: Johns Hopkins University Press.

Dinshaw, C. 1995. Chaucer's Queer Touches/A Queer Touches Chaucer. Exemplaria 7(1): 75-92.

Dinshaw, C. 1999. Getting Medieval: Sexualities and Communities, Pre-and Postmodern. Durham, NC: Duke UP.

Evrart de Conty. 1993. 2.4.1, Le visage est la partie supẽrieure du corps. In Le Livre des Eschez Amoureux Moralisés, eds. F. Guichard-Tesson and B. Roy. Montreal, Canada: Ceres.

Eyler, J., ed. 2010. Disability in the Middle Ages: Reconsiderations and Reverberations. Burlington, VT: Ashgate.

Farmer, S. 2005. The Leper in the Master Bedroom: Thinking Through a ThirteenthCentury Exemplum. In Framing the Family: Narrative and Representation in the Medieval and Early Modern Periods, eds. R. Voaden and D. Wolfthal, 79-100. Tempe, AZ: Arizona Center for Medieval and Renaissance Studies.

Foucault, M. [1972] 2006. History of Madness, trans. J. Murphy and J. Khalfa. New York: Routledge.

Freeman, E. 2000. Packing History, Count(er)ing Generations. New Literary History 31(4): 727-744.

Gerald of Wales. 1985. VIII, De rege Ricardo ab Alemannia reverso, graviter in episcopum causam Dei tuentem exacerbato (Chapter Eight, How King Richard after his return from Germany was gravely provoked against the Bishop in his defense of God's cause). In The Life of Hugh of Avalon, Bishop of Lincoln 1186-1200, ed. and trans. R.R. Loomis. New York: Garland.

Habig, M.A., ed. 1983. St. Francis of Assisi: Writings and Early Biographies, trans. R. Brown et al. 4th edn. Chicago, IL: Franciscan Herald Press.

Jacques de Vitry. 1972. Capitulum XXIX, De Hospitalibus Pauperum et Domibus Leprosorum. In The Historia Occidentalis of Jacques de Vitry, ed. J.F. Hinnebusch. Fribourg, Switzerland: University Press.

Kempe, M. 2004. In The Book of Margery Kempe, ed. B. Windeatt. Cambridge, UK: D.S. Brewer.

Koslofsky, C. 2005. The Kiss of Peace in the German Reformation. In The Kiss in History, ed. K. Harvey, 18-35. Manchester, UK: Manchester University Press.

Lindberg, C., ed. 1959. Ms. Bodley 959: Genesis-Baruch 3.20 in the Earlier Version of the Wycliffite Bible, Vol. 5. Stockholm, Sweden: Almqvist \& Wiksell.

Major, J.R. 1987. 'Bastard Feudalism' and the Kiss: Changing Social Mores in Late Medieval and Early Modern France. Journal of Interdisciplinary History 17(3): 509-535.

Marrow, J.H. 1979. Passion Iconography in Northern European Art of the Late Middle Ages and Early Renaissance. Kortrijk, Belgium: Van Ghemmert.

McNamer, S. 2010. Affective Meditation and the Invention of Medieval Compassion. Philadelphia, PA: University of Pennsylvania Press. 
McRuer, R. 2006. Crip Theory: Cultural Signs of Queerness and Disability. New York: New York University Press.

Metzler, I. 2006. Disability in Medieval Europe: Physical Impairment in the High Middle Ages, c. 1100-c. 1400. London: Routledge.

Metzler, I. 2011. Disability in the Middle Ages: Impairment at the Intersection of Historical Inquiry and Disability Studies. History Compass 9(1): 45-60.

Ogden, M., ed. 1971. The Cyrurgie of Guy de Chauliac, Early English Text Society o.s. 265. Oxford, UK: Oxford University Press.

Isidore of Seville. 1996-2011. Etymologiarum Libri. Patrologia Latina: The Full Text Database. ProQuest LLC. Vol. 82, http://gateway.proquest.com/openurl?url_ver=Z39 .88-2004\&res_dat=xri:pld-us\&rft_dat=xri:pld:ft:all:Z300018272.

Pearman, T.V. 2010. Women and Disability in Medieval Literature. New York: Palgrave.

Perella, N.J. 1969. The Kiss Sacred and Profane: An Interpretive History of Kiss Symbolism and Related Religio-Erotic Themes. Berkeley, CA: University of California Press.

Peyroux, C. 2000. The Leper's Kiss. In Monks and Nuns, Saints and Outcasts: Religion in Medieval Society, eds. S. Farmer and B.H. Rosenwein. Ithaca, NY: Cornell University Press.

Price, J. and M. Shildrick. 2002. Bodies Together: Touch, Ethics and Disability. In Disability/Postmodernity, eds. M. Corker and T. Shakespeare, 62-75. New York: Continuum.

Rawcliffe, C. 2006. Leprosy in Medieval England. Woodbridge, UK: Boydell Press.

Raymond of Capua. 1980. The Life of Catherine of Siena, trans. C. Kearns. Wilmington, DE: Michael Glazier.

Saaymen, W. and J. Kriel. 1992. AIDS: The Leprosy of Our Time? Johannesburg, South Africa: Orion Publishers.

Singer, J. 2010. Toward a Transhuman Model of Medieval Disability. postmedieval 1(1-2): 173-179.

Snyder, S. and D. Mitchell. 2006. Afterword - Regulated Bodies: Disability Studies and the Controlling Professions. In Social Histories of Disability and Deformity, eds. D.M. Turner and K. Stagg, 175-189. New York: Routledge.

Thomas Aquinas. 1928. The Summa Contra Gentiles, Vol. 3, Part 2, trans. English Domincan Fathers. London: Burns, Pates and Washbourne.

Thomson, R.G. 1997. Extraordinary Bodies: Figuring Physical Disability in American Culture and Literature. New York: Columbia University Press.

Touati, F.-O. 2000. Contagion and Leprosy: Myth, Ideas and Evolution in Medieval Minds and Societies. In Contagion: Perspectives from Pre-Modern Societies, eds. L. Conrad and D. Wujastyk, 179-201. Aldershot, UK: Ashgate.

West, N. [1933] 1962. Miss Lonelyhearts and The Day of the Locust. New York: New Directions.

Wheatley, E. 2010. Stumbling Blocks Before the Blind: Medieval Constructions of a Disability. Ann Arbor, MI: University of Michigan Press. 